\title{
Toxicity evaluation of vinasse and biosolid samples in diplopod midgut: heat shock protein in situ localization
}

\author{
Maria Paula Mancini Coelho ${ }^{1} \cdot$ Cristina Moreira-de-Sousa $^{1} \cdot$ Raphael Bastão de Souza $^{1}$. \\ Yadira Ansoar-Rodríguez ${ }^{1}$ • Elaine Cristina Mathias Silva-Zacarin ${ }^{2}$. \\ Carmem Silvia Fontanetti ${ }^{1}$
}

Received: 8 March 2017 / Accepted: 10 July 2017 / Published online: 7 August 2017

(C) Springer-Verlag GmbH Germany 2017

\begin{abstract}
Large amounts of residues generated by agricultural, urban and industrial activities are dumped daily on the soil. This practice deserves special attention because it causes serious environmental problems. This study evaluated the toxic potential of the sugarcane vinasse, a byproduct of the sugar-alcohol industry, and the biosolid, a residue produced by wastewater treatment plants, both widely used as fertilizers. The evaluation was performed through bioassays using a typical soil bioindicator, the diplopod Rhinocricus padbergi. The specimens were exposed to soils containing these residues in concentrations that are compatible with the Brazilian regulation for agricultural use. Semi-quantitative immunolabelling analyses of the stress protein HSP70 were performed on the midgut of the studied diplopods. There was a significant increase in the immunolabelling of HSP70 proteins as a response to xenobiotics from both residues, particularly in regions where the function of the cells is the detoxification of the organ (e.g. the hepatic cell layer and specific regions of the epithelium). Higher immunolabelling was observed in the specimens exposed to vinasse in comparison with the biosolid exposure. This demonstrates that the substances in the tested residues had proteotoxic action in the exposed animals and induced a cytoprotective response,
\end{abstract}

Responsible editor: Philippe Garrigues

Carmem Silvia Fontanetti

fontanet@ rc.unesp.br

1 Department of Biology, Biosciences Institute, UNESP (São Paulo State University), Av. 24-A, 1515, Rio Claro, São Paulo 13506-900, Brazil

2 Department of Biology, CCHB, UFSCar (Universidade Federal de São Carlos), Sorocaba, São Paulo, Brazil which led to higher stress protein immunolabelling. Therefore, caution is needed for the use of such residues in agriculture.

Keywords Soil toxicity $\cdot$ Fertilizers $\cdot$ Millipedes · R. padbergi $\cdot$ Immunohistochemistry $\cdot$ HSP70

\section{Introduction}

One of the biggest concerns about environmental quality is the impact of large amounts of organic residues produced on a daily basis by agricultural, urban and industrial activities and deposited in aquatic and terrestrial ecosystems. The detection and quantification of the toxic substances contained in these residues is difficult and problematic due to their complex nature. Thus, in addition to the physicochemical analysis currently performed, complementary studies are necessary to distinguish between inert and contaminant components. In this sense, toxicity tests using bioindicators have been considered an important tool to evaluate the risks of these residues to both human health and the environment (Costa et al. 2008; Fontanetti et al. 2011).

The disposal of organic residues in terrestrial environments is practical and economically advantageous. However, this action may cause soil contamination. Despite their potentially pollutant characteristics, complex residues such as those produced by the sugar-alcohol industry and wastewater treatment plants are widely used as fertilizers due to their high level of organic matter.

Several studies (Canellas et al. 2003; Barros et al. 2010; Da Silva et al. 2014) have reported the advantages of using sugarcane vinasse, the main residue produced by the sugar- 
alcohol industry, in agriculture. Vinasse has a high content of water and nutrients that are essential to plants, such as potassium, nitrogen and phosphorus, which ensures crop productivity, especially for sugarcane. On the one hand, this practice has been widely used in sugarcane-producing regions, replacing the use of chemical fertilizers to supply phosphorus to the crop (Christofoletti et al. 2013). On the other hand, several studies have demonstrated the toxicity of vinasse for aquatic organisms (Kumar and Gopal 2001; Marinho et al. 2014; Correia et al. 2017) and for plants such as Allium cepa (Pedro-Escher et al. 2016; Garcia et al. 2017) and Tradescantia pallida (Pedro-Escher et al. 2014). However, little is known about the impacts of this liquid residue on the edaphic fauna (Alves et al. 2015).

Likewise, sewage sludge, a residue produced by wastewater treatment plants, has also been a concern for the scientific community due to the increasingly large amounts generated by the urban centres. Therefore, new disposal alternatives have been investigated, and the use of this residue in agriculture as a soil conditioner is considered a sustainable alternative, avoiding contaminations due to improper stowage in the ocean, for example (Lara et al. 2007; Fytili and Zabaniotou 2008). Sludge may be rich in organic matter content, in addition to nutrients such as nitrogen and phosphorus, which improve the physical properties of the soil (e.g. density and particle aggregation) (Nascimento et al. 2004; Bovi et al. 2007; Fytili and Zabaniotou 2008; Alvarenga et al. 2015; Mondal et al. 2015). However, it may also contain metals, toxic and persistent organic compounds and disease vectors (Chenon et al. 2003; Santamaría and Toranzos 2003). The metals and organic compounds may induce different classes of genetic damage in plants of agronomic importance. Bioaccumulation of toxic compounds may occur in plant tissues and offer consumers a potential risk to their health. Some procedures can be used to form a biosolid that increases the solid content while decreasing the number of pathogenic microorganisms in the sewage sludge (Haynes et al. 2009). However, studies by Christofoletti et al. $(2012,2016)$ using the plant $A$. cepa and the millipede Rhinocricus padbergi as bioindicators showed the genotoxic and toxic potential of this residue, even after treatment.

Due to their close contact with the soil, diplopods have been widely used in toxicity evaluations as test organisms for several reasons (Fontanetti et al. 2011; Souza and Fontanetti 2011): they recycle and decompose organic matter and help to humidify the soil, and they are exposed to the contaminants of the environment. In addition, these animals colonize several layers of the soil and serve as route for the transference and biomagnification of the contaminants throughout the food chain. Finally, studies show their potential as bioindicator organisms and they are easy to use in bioassays (Fontanetti et al. 2011; Christofoletti et al. 2013; Souza et al. 2014).

The success of the Brazilian millipede species R. padbergi in the evaluation of toxicity of complex substances was attested by several studies using different concentrations of vinasse (Christofoletti et al. 2016), sewage sludge (Nogarol and Fontanetti 2010; Godoy and Fontanetti 2010; Perez and Fontanetti 2011; Bozzatto and Fontanetti 2012), landfarming soil originated from oil refinery (Souza and Fontanetti 2011), and the herbicide trifluralin (Merlini et al. 2012). Thus, this organism proved to be an excellent bioindicator to evaluate soil quality (Souza and Fontanetti 2011; Souza et al. 2014).

The midgut is an excellent organ to evaluate the stressing action caused by the residues dumped on the soil. It plays an important role in the detoxification processes and excretion of xenobiotics, acting as a barrier to prevent toxic or non-essential compounds from reaching other parts of the organism (Godoy and Fontanetti 2010; Souza and Fontanetti 2011; Fontanetti et al. 2015). Additionally, the biological effects of the environmental contaminants can be measured in several levels of organization. The techniques that reveal responses at lower levels of biological organization are considered more preventive than other techniques, and can then be used to provide an early warning of environmental risk (Nascimento et al. 2008; Souza et al. 2014).

In this context, a tool that has been shown to be increasingly efficient in toxicity studies is the use of molecular markers such as heat shock proteins (HSPs) or cellular stress proteins (Mukhopadhyay et al. 2003; Danish et al. 2015; Rahul et al. 2015). These proteins are ubiquitously distributed and evolutionarily conserved among organisms, from bacteria to mammals. They have a cytoprotective role in the cell, responding to different stress-induced homeostatic disturbances (Liu et al. 2015).

Several studies have reported that HSP70 proteins function as metabolic detoxification activators induced by a variety of stress stimuli (pathological and environmental), such as toxic and carcinogenic chemical compounds, pesticides, metals and pathogens (Kiang and Tsokos 1998;Mukhopadhyay et al. 2003; Sreedhar and Csermely 2004; Mahmood et al. 2014; Liu et al. 2015). Thus, modulating the expression HSP70 in organisms exposed to proteotoxic agents has been considered a cellular stress marker and an efficient biomarker for risk assessment (Souza et al. 2014; Rahul et al. 2015).

The aim of the present study was to verify the toxicity of a vinasse and a biosolid sample using immunolabelling of the cell stress proteins HSP70 in each of the different cell layers of the midgut of the diplopod R. padbergi (epithelium, muscular layer and hepatic cell layer). Diplopods were exposed to soils containing such residues at concentrations that are compatible with the Brazilian regulations concerning agricultural application. 


\section{Material and methods}

\section{Rhinocricus padbergi}

In this study, 30 individuals of $R$. padbergi were used as test organisms. In order to avoid interspecific differences concerning size or age, adults with an average size of $6 \mathrm{~cm}$ were used. The specimens were collected at UNESP, Rio Claro (22 $24^{\prime} 36^{\prime \prime} \mathrm{S} / 47^{\circ} 33^{\prime} 36^{\prime \prime} \mathrm{W}$ ), Sao Paulo, Brazil. The specimens were then acclimated in terrariums for 30 days, with a substrate composed of earth, potato and fragments of leaves and branches from the place in which they were collected. The temperature was $21 \pm 2{ }^{\circ} \mathrm{C}$ during the experiment, and the photoperiod was 12-h-light/12-h-dark.

\section{Control soil}

The control soil sample was obtained from the site where the diplopods were collected at a depth of $0-20 \mathrm{~cm}$, at the campus of UNESP Rio Claro. The soil samples were homogenized, dried, sieved at $4 \mathrm{~mm}$ and submitted to chemical analysis.

\section{Vinasse}

The effluent was collected from a sugarcane mill in the countryside of Sao Paulo, Brazil ( $\left.22^{\circ} 21^{\prime} 28^{\prime \prime} \mathrm{S} / 47^{\circ} 23^{\prime} 6^{\prime \prime} \mathrm{O}\right)$. The samples were kept in a cold chamber $\left(4^{\circ} \mathrm{C}\right)$ until the start of the experiment.

\section{Biosolid}

Biosolid samples were collected from a wastewater treatment plant in the countryside of Sao Paulo State $\left(20^{\circ} 32^{\prime} 30^{\prime \prime} \mathrm{S} / 47^{\circ}\right.$ $\left.25^{\prime} 11^{\prime \prime} \mathrm{O}\right) ; 2 \mathrm{~kg}$ of the material was put in plastic bags, stored in Styrofoam boxes and kept in a cold chamber $\left(4^{\circ} \mathrm{C}\right)$.

\section{Chemical characterization of the samples}

The chemical and physicochemical analyses of the control soil and vinasse samples were performed by the laboratory ASL Environmental Analysis (Rio Claro, Sao Paulo, Brazil). The characterization of soil samples was based on macronutrients and micronutrients $(\mathrm{P}, \mathrm{K}, \mathrm{Ca}, \mathrm{Mg}, \mathrm{Al})$, organic matter, $\mathrm{pH}$, cation exchange capacity (CEC), percent base saturation and aluminium saturation. The characterization of vinasse samples was based on the content of trace elements (Al, Sb, As, Ba, B, $\mathrm{Cd}, \mathrm{Pb}, \mathrm{Co}, \mathrm{Cu}, \mathrm{Cr}, \mathrm{Fe}, \mathrm{Mg}, \mathrm{Hg}, \mathrm{Mo}, \mathrm{Ni}, \mathrm{Ag}, \mathrm{Se}, \mathrm{V}, \mathrm{Zn}$ ), on the agronomic potential (organic carbon, electrical conductivity, nitrate nitrite nitrogen, Kjeldahl nitrogen, ammoniacal nitrogen, total sodium, total potassium, total calcium, total magnesium, potassium oxide, total suspended solids) and on the COD (chemical oxygen demand) and BOD (biological oxygen demand) as well.
The characterization of the biosolid sample was performed by the Laboratory TASQA (Paulinia, Sao Paulo, Brazil) based on the metal concentration (As, $\mathrm{Ba}, \mathrm{Cd}, \mathrm{Pb}, \mathrm{Cu}, \mathrm{Cr}, \mathrm{Mb}, \mathrm{Ni}$, total $\mathrm{K}, \mathrm{Se}, \mathrm{Na}, \mathrm{Zn}$ ) and on the 16 priority organic compounds (polycyclic aromatic hydrocarbons, PAHs) defined by the Environmental Protection Agency (EPA), in addition to the agronomic potential (organic carbon, electrical conductivity, $\mathrm{pH}$, nitrate nitrite nitrogen, Kjeldahl nitrogen, ammoniacal nitrogen, total sodium, total potassium, total calcium, total magnesium and total solids).

\section{Vinasse application calculation, in compliance with CETESB Technical Standard Norm P4.231}

The maximum dosage of vinasse used was determined in accordance with the Technical Standard Norm P4.231 of the Environmental Sanitation Technology Company (CETESB, 2015), the governmental agency responsible for the control and fiscalization of polluting activities in the state of São Paulo, Brazil.

\section{Sewage sludge application calculation, in compliance with CONAMA Law 375/2006}

According to the Law 375/2006 of the National Environment Council (CONAMA), the maximum annual application of sewage sludge and derivatives, in tons per hectare, shall not exceed the quotient between the quantity of nitrogen recommended for the crop (in $\mathrm{kg} / \mathrm{ha}$ ), following the official recommendation for Sao Paulo State, and the nitrogen content available in the sewage sludge or derivatives (in $\mathrm{kg} / \mathrm{t}$ ), calculated as $\mathrm{N}$ recommended $(\mathrm{kg} / \mathrm{ha}) / \mathrm{N}$ available $(\mathrm{kg} / \mathrm{t})$.

Mineralization fractions were calculated to determine the nitrogen available in the sewage sludge and/or biosolid. According to CONAMA, this fraction represents $20 \%$ of digested sewage sludge (biosolid).

\section{Preparation of soil and residue samples for the bioassays with R. padbergi}

After the chemical analysis of the samples, the volume and density of the soil were established to prepare the bioassays. Regarding the biosolid sample, the application rate is given considering the content of nitrogen needed for the crop and the content of nitrogen present in the sewage sludge or derivatives. The crop considered in this study was sugarcane, whose recommended nitrogen content is $120 \mathrm{~kg} \mathrm{~N} / \mathrm{ha}$, according to Raij and Cantarella (1997). However, the value considered in our experiment was $100 \mathrm{~kg} / \mathrm{ha}$, which is the nitrogen content usually used by Brazilian sugarcane mills.

Three terrariums with capacity for $22.5 \mathrm{~L}$ (L $45 \mathrm{~cm}, W$ $25 \mathrm{~cm}, \mathrm{H} 20 \mathrm{~cm}$ ) were filled with $5 \mathrm{~kg}$ of control soil each. The data obtained from the physicochemical analyses of the 
soil and residue samples was inserted in equations established by the pertinent regulation to calculate the amount of residues to be applied.

The following bioassays were prepared containing the control soil (CS), soil + sugarcane vinasse (SV), soil + biosolid (SB):

\section{CS: $5 \mathrm{~kg}$ of control soil}

2. SV: $5 \mathrm{~kg}$ of control soil $+668.25 \mathrm{~mL}$ of sugarcane vinasse

3. SB: $5 \mathrm{~kg}$ of control soil $+250.63 \mathrm{~g}$ of biosolid

Ten diplopods of the species $R$. padbergi were placed in each terrarium for 30 days. The temperature was $21 \pm 2{ }^{\circ} \mathrm{C}$ during the experiment, and the photoperiod was 12-h-light/12h-dark.

\section{Animal dissection}

After a 30-day exposure period, three animals from each treatment group were anaesthetized with sulphur ether and dissected in physiological saline for removal of the midgut. Portions of the organ were fixed in $4 \%$ paraformaldehyde for $24 \mathrm{~h}$. Then, the material was placed in phosphate-buffered saline (PBS; pH 7.4) and stored in cold chamber at $4{ }^{\circ} \mathrm{C}$.

\section{Immunohistochemistry of the midgut}

The fixed material was dehydrated in increasing concentrations of cold ethanol $(15,30,50,70,85,90$ and $95 \%)$ for $20 \mathrm{~min}$ in each bath. The material was then transferred to a xylol + ethanol mixture for $20 \mathrm{~min}$ and then to xylol, also for $20 \mathrm{~min}$; the latter step was performed twice. Next, the material was embedded three times in liquid paraffin (Paraplast), remaining in paraffin for $8 \mathrm{~h}$ each time. After the inclusion, the material was sectioned at $6 \mu \mathrm{m}$ thickness using a microtome. The sections were then hydrated and transferred to slides.

The immunohistochemistry was performed according to the adapted protocol proposed by Silva-Zacarin et al. (2012). The paraffin was removed from the slides with 10-min baths in solutions of xylene, xylene + alcohol and absolute alcohol. After deparaffinization, the slides were gradually hydrated in a series of alcohols $(95,80,70,50 \%)$ and distilled water. The sections were then permeabilized with Triton X-100 to ensure free access of the antibody to the antigen, and washed with PBS.

For HSP70 immunolabelling, anti-HSP70 (monoclonal antibody produced in mouse; Sigma, St. Louis, MO, USA; 1:100 dilution) was used with anti-mouse whole molecule IgG conjugated with alkaline phosphatase (Sigma, St. Louis, MO, USA; 1:100 dilution) as the secondary antibody. After the blockage step, slides were incubated in a humid chamber at $37{ }^{\circ} \mathrm{C}$ for binding of the respective antibodies. The Kit EnVision (Dako ${ }^{\mathrm{TM}}$ ) G|2 System/AP Rabbit/Mouse
(Permanent Red) was used to reveal the immunolabelling. To access the efficiency of the immunohistochemical detection of HSP70, slides without the primary antibody incubation were made and showed no immunolabelling.

\section{Immunohistochemical analysis}

All the slides were analysed under light microscope using $\times 10, \times 20$ and $\times 40$ objective lens (total magnification of $\times 100, \times 200$ and $\times 400$, respectively). Three randomly selected fields of each histological section, in a total of 60 nonconsecutive sections per group, were captured with a camera (magnification of $\times 400$ ) attached to the microscope, using the Leica QWin Standard v. 2.8 program. Positive labelling was considered when a red-pink colour was observed, indicating the deposition of the chromogen in the antigen-antibodybinding sites. Intensity may vary according to the amount of HSP70 protein present in the cells. Absence of such coloration attested negative labelling.

Considering the portion of the organ, a semi-quantitative evaluation of protein immunolabelling in digitized images was performed according to the following the scale: $-=$ no immunolabelling, $+=$ weak immunolabelling, $++=$ moderate immunolabelling and $+++=$ intense immunolabelling. The mean percentage of labelling per individual results was quantified, and the mean percentage of the individuals was calculated considering the proportionality between the number observed in each labelling intensity and the number of fields assessed in each individual (60 on average). The percentage result for each group (CS, SV, SB) was obtained using the mean percentage of each individual of the groups.

To complement this analysis, a secondary semiquantitative analysis was done. The digitized images were transferred to the program ImageJ v. 1.31 (available as freeware from http://rsbweb.nih.gov/ij/), which provided the percentage of intense immunolabelled area detected by contrast in relation to the total area analysed in each histological section. The data obtained through this semiquantitative evaluation of each treatment (exposure to vinasse and biosolid) was compared with the results obtained for the individuals exposed to the control soil sample using parametric statistics tests one-way ANOVA and Tukey's post hoc test, $p<0.001$.

\section{Results}

\section{Chemical characterization of the samples}

Table 1 shows data regarding agronomic potential and fertility of the control soil for the correct application of the residues according to the Brazilian legislation. The results obtained by the physicochemical analysis of vinasse and biosolid samples 
Table 1 Data regarding the fertility of the control soil

\begin{tabular}{llllllllll}
\hline Sample & $\begin{array}{l}\mathrm{pH} \\
\left(\mathrm{CaCl}_{2}\right)\end{array}$ & $\begin{array}{l}\mathrm{OM} \\
\left(\mathrm{g} / \mathrm{dm}^{3}\right)\end{array}$ & $\begin{array}{l}\mathrm{P} \\
\left(\mathrm{mg} / \mathrm{dm}^{3}\right)\end{array}$ & $\begin{array}{l}\mathrm{K} \\
\left(\mathrm{mmol}_{\mathrm{c}} / \mathrm{dm}^{3}\right)\end{array}$ & $\begin{array}{l}\mathrm{Ca} \\
\left(\mathrm{mmol}_{\mathrm{c}} / \mathrm{dm}^{3}\right)\end{array}$ & $\begin{array}{l}\mathrm{Mg} \\
\left(\mathrm{mmol}_{\mathrm{c}} / \mathrm{dm}^{3}\right)\end{array}$ & $\begin{array}{l}\mathrm{H}+\mathrm{Al} \\
\left(\mathrm{mmol}_{\mathrm{c}} / \mathrm{dm}^{3}\right)\end{array}$ & $\begin{array}{l}\mathrm{SB} \\
\left(\mathrm{mmol}_{\mathrm{c}} / \mathrm{dm}^{3}\right)\end{array}$ & $\begin{array}{l}\mathrm{CEC} \\
\left(\mathrm{mmol}_{\mathrm{c}} / \mathrm{dm}^{3}\right)\end{array}$ \\
\hline Soil & 6 & 85 & 22 & 2.9 & 199 & 55 & 14 & 256.9 & 270.9 \\
\hline
\end{tabular}

$O M$ organic matter, $C E C$ cation exchange capacity, $S B$ sum of the bases, $V$ base saturation

are presented in Tables 2, 3 and 4. Except for nickel, all the parameters for the sugarcane vinasse were in compliance with the Guiding Values for Underground Water CETESB-195/ 2005. Regarding the biosolid sample, all the parameters were in compliance with the CONAMA Law 375/2006, which regulates the disposal of sewage sludge and derivatives.

\section{Immunohistochemistry}

Immunolabels were analysed in each of the different cellular layers that constitute the midgut of millipedes: epithelium (apical and basal portions), muscular layer and hepatic cell layer (Fig. 1a). The control group showed evident but weak immunolabelling $(+)$ in the basal portion of the epithelium and a mostly moderate $(++)$ for the apical region of the epithelium and for the hepatic cell layer (Figs. 1b, 2, 3 and 4). In the muscular layer supporting the epithelium, there was no immunolabelling for HSP70 (Fig. 1b). Using ImageJ, the control group showed the lowest mean percentage of the intensely immunolabelled area $(3.41 \%)$ in comparison to the exposed groups (Fig. 5).

The group exposed to vinasse showed $8.05 \%$ of intensely imunolabelled area, a statistically different $(p<0.001)$ result in comparison with the control and the exposed to biosolid group (Fig. 5). Only the exposed groups showed strong immunolabelling for both apical and basal portions of the epithelium, where the regenerative cells are located. The hepatic cell layer also showed an increase in the area of intense immunolabelling $(+++)$ in comparison with the other groups (Figs. 1c, 2, 3 and 4).

The group exposed to the biosolid showed an increase in the labelling of the apical and basal portions of the epithelium and in the hepatic cell layer when compared to the control group. This labelling was less intense in comparison with the group exposed to vinasse (Figs. 1d, 2, 3 and 4). According to the ANOVA $(p<0.001)$, there was no significant difference between the percentage of intensely labelled areas in this group (4.17\%) and the control group $(3.41 \%)$ (Fig. 5).

\section{Discussion}

The heat shock protein HSP70 is stored in distinct subcellular compartments, including the cytoplasm, mitochondria and endoplasmic reticulum (Boorstein et al. 1994; Mayer and Bukau
Table 2 Physicochemical analysis of vinasse and biosolid sample

\begin{tabular}{llllll}
\hline Parameter & Samples & & $\begin{array}{l}\text { GVP } \\
(\mathrm{mg} / \mathrm{kg})\end{array}$ & $\begin{array}{l}\text { MCA } \\
(\mathrm{mg} / \mathrm{kg})\end{array}$ & Method \\
\cline { 2 - 4 } & $\mathrm{V}(\mathrm{mg} / \mathrm{L})$ & $\mathrm{B}(\mathrm{mg} / \mathrm{kg})$ & & & EPA 6010 C \\
\hline Total calcium & 828 (dilution 25) & 3197 & - & & EPA 6010 C \\
Total sulphur & - & 1215 & - & - & EPA 6010 C \\
Total phosphorus & - & 11,039 & - & - & EPA 6010 C \\
Total magnesium & 321.250 (dilution 25) & 1397 & - & - & SM22 4500B \\
Nitrite & $<$ LQ & 25.5 & - & - & SM22 4500 E \\
Ammoniacal nitrogen & 10.920 & 4813 & - & - & SM22 4500 B \\
Kjeldahl nitrogen & 234.1 & 11,122 & - & - & EPA 9045 C \\
pH & 4.14 & 7.6 & - & - & EPA 6010 C \\
Total potassium & $3276($ dilution 100) & 3221 & - & - & EPA 6010 C \\
Total sodium & 13.57 & 520 & - & - & SM22 2540 B \\
Solid content (mg/L) & 1190 & 185,162 & - & - & SM22 2540 B \\
Moisture (g/g) & - & 0.8148 & - & - & \\
\hline
\end{tabular}

$V$ sugarcane vinasse, $B$ biosolid, $Q L$ quantification limit, GVP Guiding Values of Prevention and Intervention for Soil and Groundwater according to CETESB (195/2005-E), MCA maximum concentration allowed in sewage sludge and derivatives according to CONAMA (375/2006), SM22 Standard Methods for the Examination of Water and Wastewater 22th Edition 2012, EPA Environmental Protection Agency, SSSA chapter 34 Soil Science Society of America, Methods of Soil Analysis - Part 3 - Chemical methods 
Table 3 Metal analysis of the vinasse and biosolid sample

\begin{tabular}{|c|c|c|c|c|c|}
\hline \multirow[t]{2}{*}{ Parameter } & \multicolumn{2}{|l|}{ Samples } & \multirow{2}{*}{$\begin{array}{l}\text { GVP } \\
(\mathrm{mg} / \mathrm{kg})\end{array}$} & \multirow{2}{*}{$\begin{array}{l}\mathrm{MCA} \\
(\mathrm{mg} / \mathrm{kg})\end{array}$} & \multirow[t]{2}{*}{ Method } \\
\hline & $\mathrm{V}(\mathrm{mg} / \mathrm{L})$ & $\mathrm{B}(\mathrm{mg} / \mathrm{kg})$ & & & \\
\hline Arsenic & $<\mathrm{LQ}$ & $<\mathrm{LQ}$ & 0.01 & 41 & EPA $6010 \mathrm{C}$ \\
\hline Barium & 0.218 & 174 & 0.7 & 1300 & EPA $6010 \mathrm{C}$ \\
\hline Cadmium & $<\mathrm{LQ}$ & $<\mathrm{LQ}$ & 0.005 & 39 & EPA $6010 \mathrm{C}$ \\
\hline Lead & $<\mathrm{LQ}$ & 26 & 0.01 & 300 & EPA $6010 \mathrm{C}$ \\
\hline Copper & 0.155 & 153 & 2 & 1500 & EPA $6010 \mathrm{C}$ \\
\hline Chromium & $<\mathrm{LQ}$ & 128 & 0.05 & 1000 & EPA $6010 \mathrm{C}$ \\
\hline Mercury & $<\mathrm{LQ}$ & 0.25 & 0.001 & 17 & EPA 7470 A \\
\hline Molybdenum & $<\mathrm{LQ}$ & 6.17 & 0.07 & 50 & EPA $6010 \mathrm{C}$ \\
\hline Nickel & 0.029 & 40.9 & 0.02 & 420 & EPA $6010 \mathrm{C}$ \\
\hline Selenium & $<\mathrm{LQ}$ & $<\mathrm{LQ}$ & 0.01 & 100 & EPA $6010 \mathrm{C}$ \\
\hline Zinc & 0.625 & 312 & 5 & 2800 & EPA $6010 \mathrm{C}$ \\
\hline
\end{tabular}

$V$ sugarcane vinasse, $B$ biosolid, $Q L$ quantification limit, GVP Guiding Values of Prevention and Intervention for Soil and Groundwater according to CETESB (195/2005-E), MCA maximum concentration allowed in sewage sludge and derivatives according to CONAMA (375/2006), EPA Environmental Protection Agency, SSSA chapter 34 Soil Science Society of America, Methods of Soil Analysis - Part 3-Chemical methods
2005; Wang et al. 2013). These proteins have specific functions in the signalling pathways related to cell growth and in the prevention or reversal of proteotoxic damages caused by stress, including oxidative stress (Polla et al. 1996). Despite the nomenclature of these proteins, several other adverse factors can lead to an increase in HSP synthesis in addition to increased temperatures: chemical, physical and biological

Table 4 Analysis of polycyclic aromatic hydrocarbons in raw samples of biosolid sample

\begin{tabular}{llll}
\hline Parameter & $\mathrm{B}(\mu \mathrm{g} / \mathrm{kg})$ & Method & $\mathrm{CO}(\mathrm{mg} / \mathrm{kg})$ \\
\hline Acenaphthene & $<\mathrm{LQ}$ & EPA 8270 D & - \\
Acenaphthylene & $<\mathrm{LQ}$ & EPA 8270 D & - \\
Anthracene & $<\mathrm{LQ}$ & EPA 8270 D & - \\
Benzo(a)anthracene & $<\mathrm{LQ}$ & EPA 8270 D & 0.025 \\
Benzo(a)pyrene & $<\mathrm{LQ}$ & EPA 8270 D & 0.052 \\
Benzo(b)fluoranthene & $<\mathrm{LQ}$ & EPA 8270 D & 0.38 \\
Benzo(g,h,i)perylene & $<\mathrm{LQ}$ & EPA 8270 D & 0.57 \\
Benzo(k)fluoranthene & $<\mathrm{LQ}$ & EPA 8270 D & 0.38 \\
Chrysene & $<\mathrm{LQ}$ & EPA 8270 D & 8.1 \\
Dibenzo(a,h)anthracene & $<\mathrm{LQ}$ & EPA 8270 D & 0.08 \\
Phenanthrene & $<\mathrm{LQ}$ & EPA 8270 D & 3.3 \\
Fluoranthene & $<\mathrm{LQ}$ & EPA 8270 D & - \\
Fluorene & $<\mathrm{LQ}$ & EPA 8270 D & - \\
Indeno(1,2,3-cd)pyrene & $<\mathrm{LQ}$ & EPA 8270 D & 0.031 \\
Naphthalene & $<\mathrm{LQ}$ & EPA 8270 D & 0.12 \\
Pyrene & $<\mathrm{LQ}$ & EPA 8270 D & - \\
\hline
\end{tabular}

$B$ biosolid, $L Q$ limits of quantification, EPA $8270 \mathrm{D}$ method used to determine the concentration of semi-volatile organic compounds in extracts prepared from many types of solid waste matrices, $\mathrm{CO}$ maximum concentration allowed in the soil according to CONAMA (375/2006) inducers (metals, metabolism inhibitors, xenobiotics, chemotherapeutic agents, infections), including the cell division cycle and growth factors, common cell mechanisms (Erata et al. 2005).

All these characteristics combined with the occurrence of HSP70 in all eukaryotic organisms allow this protein to be considered as an excellent biomarker in the ecotoxicology field. It acts as a link between toxicant exposure and the ecologically relevant effects in a population or community level. A significant increase in the expression of HSP70 protein is evidence of environmental alterations, as it acts on the renaturation or removal of denatured proteins, which would be cytotoxic (Köhler et al. 1995; Nadeau et al. 2001; Malaspina and Silva-Zacarin 2006; Souza et al. 2014; Lüchmann et al. 2015).

Despite its potential as a biomarker of environmental pollution, studies that evaluate the expression of HSP70 in soil invertebrates, especially diplopods, are recent and scarce (Eckwert et al. 1994; Zanger et al. 1996). To our knowledge, the present work is pioneer in quantifying areas of the midgut where the labelling of HSP70 was more intense, which indicates a larger expression in these specific regions. This may be evidence of a cytoprotective process taking place in each region of the midgut.

Considering the information above and the results of this study, it is possible to elaborate some hypotheses about HSP70 protein labelling in the midgut of the $R$. padbergi diplopod, when comparing the control group and those groups exposed to vinasse and biosolid.

Animals in the control group showed weak immunolabelling. This demonstrates that HSP70 is commonly found in the analysed organ due to its function as cell chaperone. The observation of these labellings in more specific regions of the organ 
Fig. 1 Midgut histological sections of $R$. padbergi subjected to HE technique (a), HSP70 immunohistochemistry (b-d). a, b Control group. c Group exposed to vinasse. $\mathbf{d}$ Group exposed to biosolid. $e$ epithelium; $m l$ muscular layer; $h c$ hepatic cells; bar $=20 \mu \mathrm{m}$
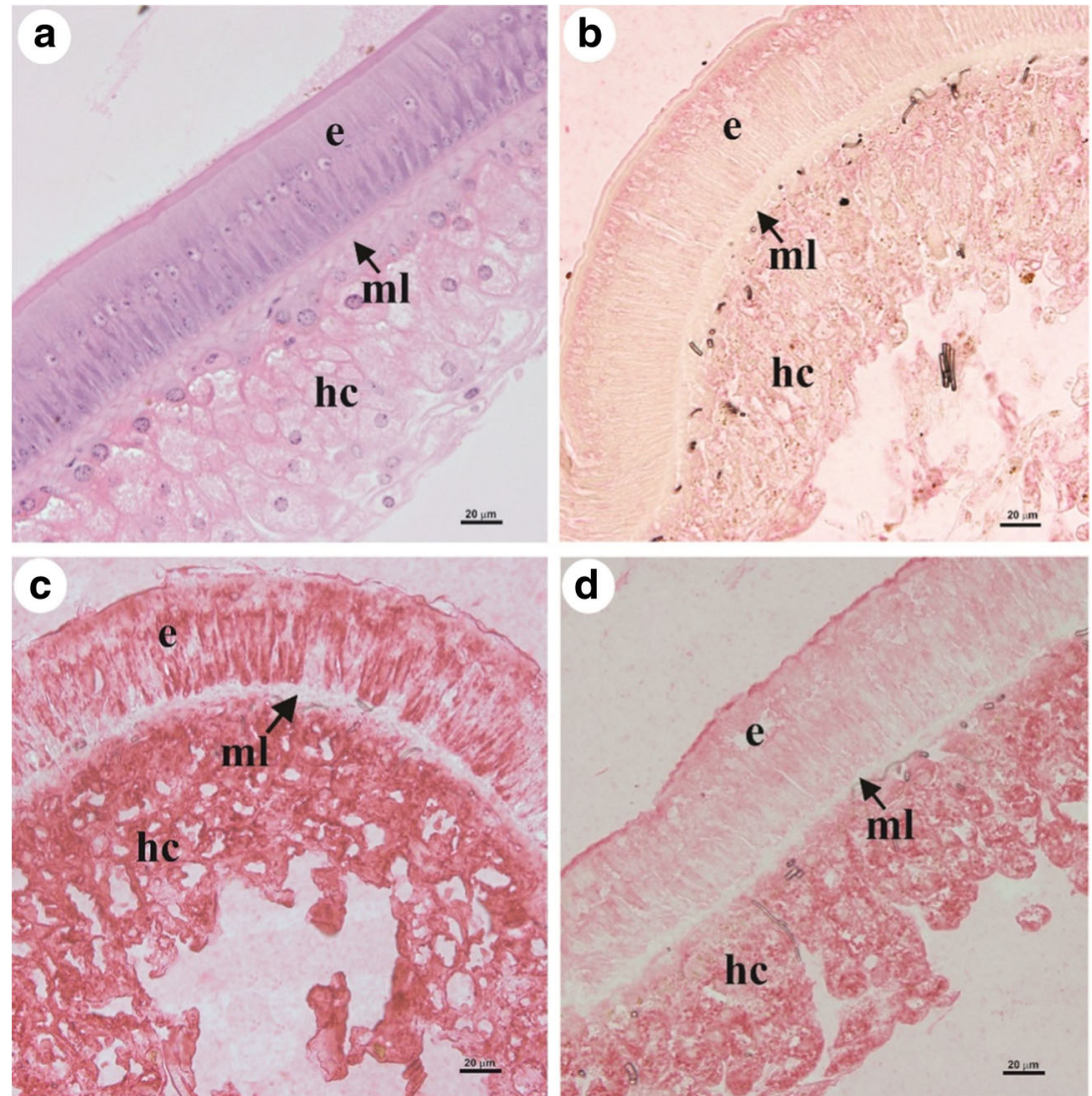

suggests that they are located preferentially in regions that participate in cytoprotective processes. One of these regions is the epithelial cells, which contribute by forming a kind of stable protective barrier for the organism against external agents. It also promotes cellular renovation, which confers protection to the organ by replacing damaged or malfunctioning cells.

The moderate immunolabelling observed in hepatic cells is explained by the role played by these cells in the organisms' detoxification process. In fact, among the

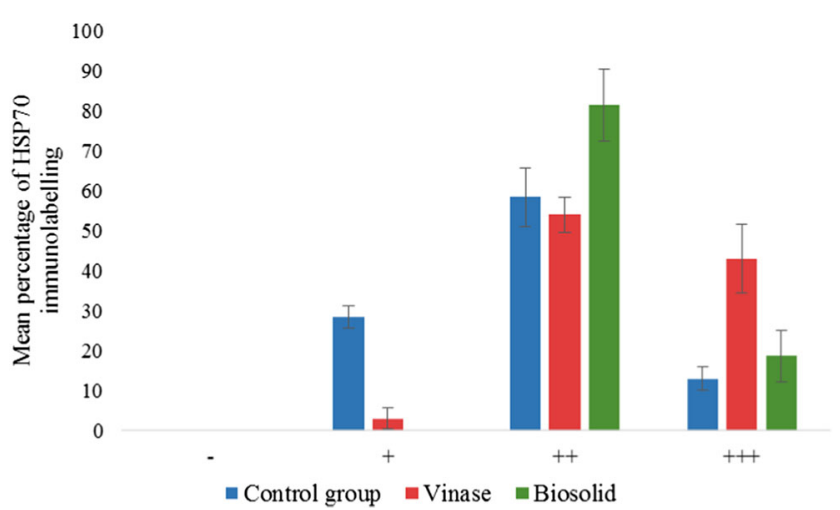

Fig. 2 Expression pattern of HSP70 in the apical portion of the midgut epithelium of $R$. padbergi. Bar diagram showing the relative intensity of HSP expression (means $\pm \mathrm{SD}$ ). Values expressed as percentage. - no immunolabelling; + weak immunolabelling; ++ moderate immunolabelling; +++ intense immunolabelling several studies done with the midgut of $R$. padbergi, all had large accumulations of spherocrystals in the hepatic cells, showing its role in the inactivation of toxic chemical compounds (Fontanetti et al. 2015). In this sense, the labelling observed in the hepatic cells in this study, for both control and exposed animals, confirms that high levels of HSP70 are responsible for cytoprotection of the cells that are subject to the action of parental molecules and secondary metabolites during the

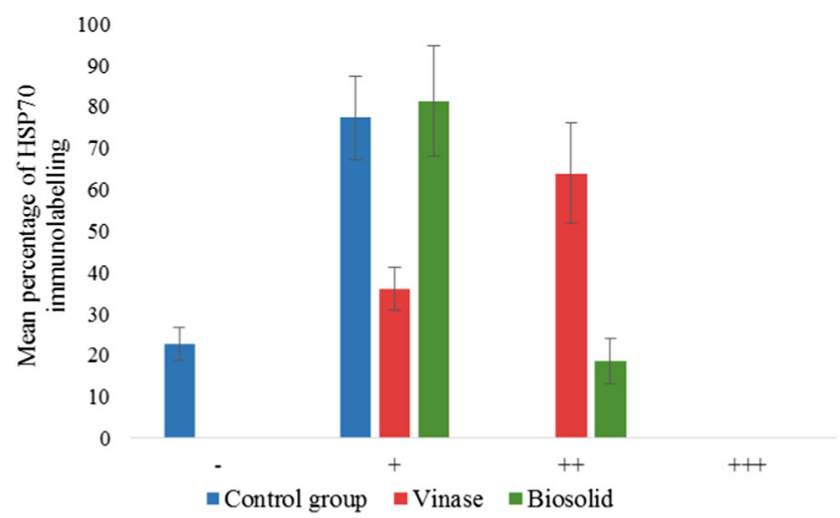

Fig. 3 Expression pattern of HSP70 in the basal portion of the midgut epithelium of $R$. padbergi. Bar diagram showing the relative intensity of HSP expression (means $\pm \mathrm{SD}$ ). Values expressed as percentage. - no immunolabelling; + weak immunolabelling; ++ moderate immunolabelling; +++ intense immunolabelling 


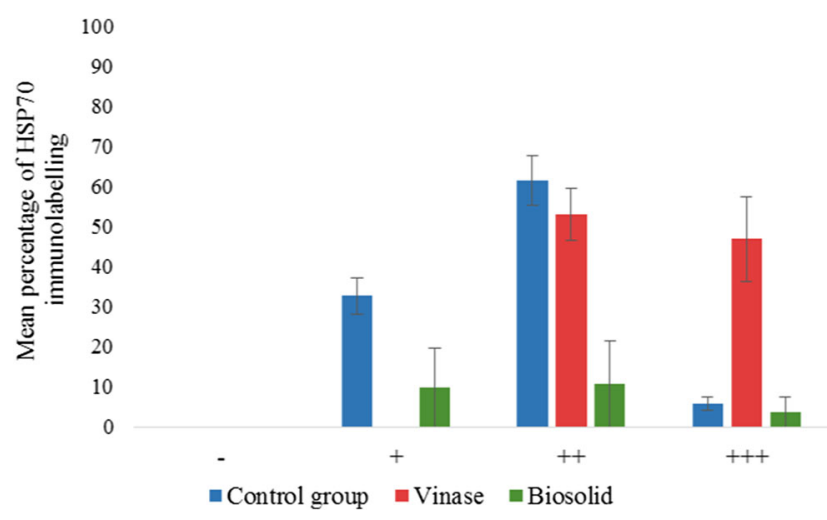

Fig. 4 Expression pattern of HSP70 in the hepatic cells of the midgut epithelium of $R$. padbergi. Bar diagram showing the relative intensity of HSP expression (means $\pm \mathrm{SD}$ ). Values expressed as percentage. - no immunolabelling; + weak immunolabelling; ++ moderate immunolabelling; +++ intense immunolabelling

biotransformation of the compounds absorbed by the intestine (Sreedhar and Csermely 2004).

It is possible to draw a parallel between the analyses performed for the midgut using light (Fantazzini et al. 2002) and transmission electron microscopy (Camargo-Mathias et al. 2004), and the immunohistochemical results found in this study.

The epithelium of $R$. padbergi is pseudostratified and composed of absorptive (or principal) cells intercalated by regenerative and secretory cells (Fantazzini et al. 2002; CamargoMathias et al. 2004). The absorptive cells present a welldeveloped brush border, and are involved in the processes of food absorption and in the transportation of elements to the haemolymph as well. However, studies have reported that these cells accumulate metals, such as lead, cadmium, zinc, copper (Köhler et al. 1995) and calcium (Fantazzini et al. 2002). The presence of metals or toxic substances can induce an increase in the HSP70 expression (Erata et al. 2005) as the absorptive cells react to protect the organism from harmful

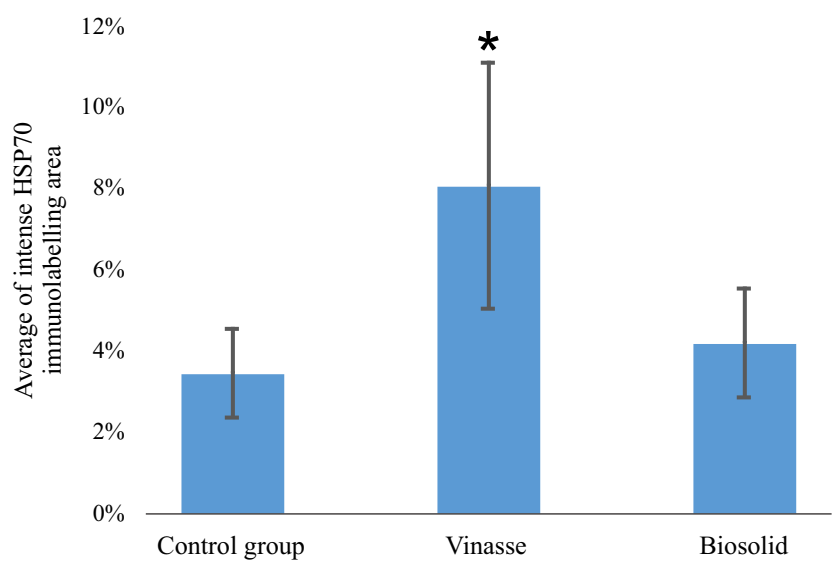

Fig. 5 Average of intense HSP70 immunolabelling area detected by contrast in relation to the total area analysed in the midgut of $R$. padbergi obtained using the ImageJ program (means $\pm \mathrm{SD}$ ). Values expressed as percentage. * Statistically significant when compared to the other groups by one-way ANOVA/Tukey, $p<0,01$ substances (Fontanetti et al. 2015). Considering this, it is suggested that the higher concentration of HSP70 protein in these cells is a response to the experimental situation that induced the cell stress in this study, mainly to the exposure to vinasse and, in lower intensity, to the biosolid.

The regenerative cells, located in the basal region of the epithelium along the midgut, are responsible for the epithelial renovation (Hopkin and Read 1992), besides playing the role of unipotent stem cells in diplopod midgut (Sosinka et al. 2014). Thus, the immunolabelling observed in the basal region of the midgut from the animals exposed to vinasse and to the biosolid corresponds to the region where the regenerative cells are located. This suggests that the HSP70 proteins present in these cells would have been expressed due to their activation for a possible cell renovation as a response to the stress caused by the substances present in the residues, such as metals, even in concentrations below those that are detectable by the analytical method applied.

The secretory cells, commonly observed in the midgut epithelium of several diplopods, are closely related to a cytoprotective function, as many studies have reported an increase in the number of these cells in diplopods exposed to contaminated soils (Perez and Fontanetti 2011; Nogarol and Fontanetti 2010; Merlini et al. 2012). The release of secretory vesicles is an indirect way of eliminating undesired substances from the organism (Fontanetti et al. 2015). Therefore, these cells probably participated in expression of the HSP70 proteins in the animals exposed to the substances used in this study, since the animals exposed to vinasse were significantly marked when compared to the control group.

From the ultrastructural point of view, the organelles present in the midgut cells of R. padbergi (Camargo-Mathias et al. 2004) suggest that the location of preferential regions for HSP70 protein expression is related to the position of the organelles in the cells. The presence of more intense labelling in the apical region of the epithelium could be associated with the presence of a large number of mitochondria in this site. As mitochondria occur where the energetic demand is higher, the labelling observed in the epithelium of the animals exposed to vinasse and biosolid could be associated with the sites containing a larger number of mitochondria. The HSP proteins play a fundamental role in stabilizing newly synthesized mitochondrial precursor proteins that are in the unwound form. This prevents their aggregation before the appropriated moment: the interaction with the external mitochondrial membrane translocase complex, which leads to their import and posterior winding in the interior of the organelle (Alberts et al. 2010; Gupta et al. 2010).

Overall, the differences observed between the immunolabelling intensities suggest that the exposure to vinasse triggered a heavier cytoprotective response of the organ in comparison with the biosolid. This can be due to the different potentially toxic elements (PTEs), such as trace elements (metals and metalloids), present in 
both mixtures, as they induced distinct intensities of stress response.

Metals like copper $(\mathrm{Cu})$, cobalt $(\mathrm{Co})$ and Nickel $(\mathrm{Ni})$ were detected in both samples, but only the last one in concentrations above the allowed limit for vinasse. They are capable of producing reactive radicals in cells, resulting in damage to DNA, lipid peroxidation and other effects (Valko et al. 2005). It is known that, in a molecular level, these proteins are key targets of these metallic ions, which can interfere in protein folding and consequently affect protein homeostasis and cell viability (Sharma et al. 2008, Tamás et al. 2014). Thus, induction of the HSP70 protein family can happen due to the interruption of protein homeostasis as a result of the primary and secondary effect of metals. This occurs not only due to the effect on individual proteins but also by promoting the formation of proteotoxic aggregates in a spectrum of cellular responses known as proteotoxicity (Hightower 1991; Köhler et al. 1996; Tamás et al. 2014).

In contrast, several studies have demonstrated that the amount of metals available and mobile in the soil is more predictive of the biological effects than their total concentrations (Natal-da-luz 2011), especially when it comes to terrestrial invertebrates like diplopods. Therefore, it is important to note that these metals would be strongly attached to the biosolid organic matter, limiting their potential biodisponibility in the soil (Silveira et al. 2003). In fact, Kiikkila et al. (2002) showed that biosolid can act as an organic immobilizer agent, for example by reducing the concentration of exchangeable copper. This situation does not apply to vinasse as it is as an aqueous solution in fertirrigation, which may explain the difference in the results obtained between the residues.

Diplopods, by feeding from contaminated soil, may present bioaccumulation of metals in the midgut as insoluble granules (spherocrystals) in order to neutralize the toxic effects of these compounds (Köhler 2002; Christofoletti et al. 2016). Besides that, it is known that the cellular components usually affected by metals in the midgut of diplopods are designated as heat shock protein-binding sites (Köhler et al. 1992). Moreover, the induction of HSP70 may occur before the accumulation of metals inside the cells, since its expression can be modulated by cell signal transducers, promoting a protective response before such an effect (Urani et al. 2001).

However, as these residues are complex mixtures, it is not possible to establish a direct relation between their constituents and the damage caused. Their toxicity can also be the result of additive, antagonistic or synergic effects of the substances (Natal-da-luz et al. 2009; Alves et al., 2015).

Nevertheless, some studies have demonstrated that the HSP expression response in soil invertebrates, both in laboratory and field conditions, is especially suitable to indicate the exposure effects to relatively low concentrations of several toxic substances (Kammenga et al. 2000). This can reveal sublethal damage to the cells as a result of stress triggered by environmental factors (Ryan and Hightower 1996; Mahmood et al. 2014). Nadeau et al. (2001) concluded that the induction of HSP70 could not be considered a biomarker just due to its broad spectrum of exposure but also by its effect, since known toxic agents alter the HSP70 gene expression tissues and organs of earthworms, another important group of the soil macrofauna.

\section{Conclusion}

The analyses performed in this study revealed that the exposure of the bioindicator $R$. padbergi to both organic residues used in sugarcane crops triggered interesting cell responses, which were observed in a different way in each region that comprise the animal midgut. The cytoprotective responses caused by the proteotoxic action of the residues in the midgut stimulated an increase in the expression of HSP70 stress protein family. Therefore, stronger immunolabelling for HSP70 was observed in response to vinasse when compared with the biosolid, particularly in cell regions that play a role in detoxification, such as the epithelial cells. Thus, caution is advised in the use of these residues in agriculture. In addition, these results demonstrate that the HSP70 immunolabelling technique in the test organism can be a satisfactory tool for investigation of toxic potential of environmental samples and for analysis of new substances disposed in the environment.

Acknowledgements The authors thank FAPESP (Fundação de Amparo à Pesquisa do Estado de São Paulo, process no. 2012/50197-2 and 2014/12646-5) for financial support, and Gerson Mello de Souza for his help in the laboratory.

\section{Compliance with ethical standards}

Conflict of interest The authors declare that they have no conflict of interest.

\section{References}

Alberts B, Johnson A, Lewis J, Raff M, Roberts K, Walter P (2010) Biologia Molecular da Célula, quinta ed. Artmed, Porto Alegre (in Portuguese)

Alvarenga P, Mourinha C, Farto M, Santos T, Palma P, Sengo J, Morais MC, Cunha-Queda C (2015) Sewage sludge, compost and other representative organic wastes as agricultural soil amendments: benefits versus limiting factors. Waste Manag 40:44-52

Alves PRL, Natal-da-Luz T, Sousa JP, Cardoso EJBN (2015) Ecotoxicological characterisation of sugarcane vinasses when applied to tropical soils. Sci Total Environ 526:222-232

Barros RP, Viégas PRA, Silva TL, Souza RM, Barbosa L, Viégas RA, Barreto MCV, Melo AS (2010) Alterações em atributos químicos de solo cultivado com cana-de-açúcar e adição de vinhaça. Pesq Agropec Trop 40:341-346 (in Portuguese)

Boorstein WR, Ziegelhoffer T, Craig EA (1994) Molecular evolution of the HSP70 multigene family. J Mol Evol 38(1):1-17 
Bovi MLA, Godoy-Júnior G, Costa EAD, Berton RS, Spiering SH, Vega FVA, Cembranelli MAR, Maldonado CAB (2007) Lodo de esgoto e produção de palmito em pupunheira. R Bras Ci Solo 3:153-166 (in Portuguese)

Bozzatto V, Fontanetti CS (2012) Sewage sludge toxicity in edaphic organism: analysis of midgut responses in the diplopod Rhinocricus padbergi. Microsc Res Tech 75(7):869-875

Camargo-Mathias MI, Fantazzini ER, Fontanetti CS (2004) Ultrastructural features of the midgut of Rhinocricus padbergi (diplopoda: spirobolida). Braz J Morphol Sci 21(2):65-71

Canellas LP, Velloso ACX, Marciano CR, Ramalho JFGP, Rumjanek VM, Rezende CE, Santos GA (2003) Propriedades químicas de um Cambissolo cultivado com cana-de-açúcar, com preservação do palhiço e adição de vinhaça por longo tempo. R Bras Ci Solo 27:935-944 (in Portuguese)

CETESB-Companhia de Tecnologia de Saneamento Ambiental (2005). Norma 195/2005-E: Dispõe sobre a aprovação dos Valores Orientadores para Solos e Águas Subterrâneas no Estado de São Paulo-2005, em substituição aos Valores Orientadores de 2001. 215 (in Portuguese) http://solo.cetesb.sp.gov.br/wpcontent/uploads/ sites/34/2014/12/tabela_valores_2005.pdf) Accessed 3 August 2015

CETESB-Companhia de Tecnologia de Saneamento Ambiental (2015) Norma P4.231: Vinhaça: Critérios e Procedimentos para Aplicação no Solo Agrícola (in Portuguese) http://www.cetesb.sp.gov.br/ Tecnologia/camaras/P4_231.pdf Accessed 3 August 2015

Chenon P, Gauthier L, Loubières P, Séverac A, Delpoux M (2003) Evaluation of the genotoxic and teratogenic potential of a municipal sludge and sludge-amended soil using the amphibian Xenopus laevis and the tobacco:Nicotiana tabacum L var xanthi. DulieuSci Total Environ 301:139-150

Christofoletti CA, Francisco A, Fontanetti CS (2012) Biosolid soil application: toxicity tests under laboratory conditions. Appl Environ Soil Sci 2012:1-9

Christofoletti CA, Pedro-Escher J, Correia JA, Marinho JFU, Fontanetti CS (2013) Sugarcane vinasse: environmental implications of its use. Waste Manag 33:2752-2761

Christofoletti CA, Francisco A, Pedro-Escher J, Gastaldi VD, Fontanetti CS (2016) Diplopods as soil bioindicators of toxicity after application of residues from sewage treatment plants and ethanol industry. Microsc Microanal 22:1098-1110

CONAMA-Conselho Nacional do Meio Ambiente (2006) Resolução 375/2006. Define critérios e procedimentos, para o uso agrícola de lodos de esgoto gerados em estações de tratamento de esgoto sanitário e seus produtos derivados, e dá outras providências (in Portuguese) http://www.mma.gov.br/port/conama/res/res06/ res37506.pdf). Accessed 3 August 2015

Correia JE, Christofoletti CA, Marcato ACC, Marinho JFU, Fontanetti CS (2017) Histopathological analysis of tilapia gills (Oreochromis niloticus Linnaeus, 1758) exposed to sugarcane vinasse. Ecotox Environ Saf 135:319-326

Costa CR, Olivi P, Botta CM, Espindola EL (2008) A toxicidade em ambientes aquáticos: discussão e métodos de avaliação. Quim Nova 31(7): 1820-1830 (in Portuguese)

Da Silva APM, Bono JAM, Pereira FAR (2014) Aplicação de vinhaça na cultura da cana-de-açúcar: Efeito no solo e na produtividade de colmos. Rev Bras Eng Agríc Ambient 18(1):38-43 (in Portuguese)

Danish M, Fatima A, Khanam S, Jyoti S, Ali F, Naz F, Siddique YH (2015) Evaluation of the toxic potential of calcium carbide in the third instar larvae of transgenic Drosophila melanogaster (hsp70lacZ) Bg9. Chemosphere 139:469-478

Eckwert H, Zanger M, Reiss S, Musolff H, Alberti G, Köhler HR (1994) The effect of heavy metals on the expression of hsp 70 in soil invertebrates. Verh Dtsch Zool Ges 87(1):325

Erata GO, Kanbagli O, Durlanik O, Bulut T, Toker G, Uysal M (2005) Induced oxidative stress and decreased expression of inducible heat schock protein (hsp70) in patient with colorectal adenocarcinomas. Jpn J Clin Oncol 35(2):74-78

Fantazzini ER, Fontanetti CS, Camargo-Mathias MI (2002) Midgut of the millipede "Rhinocricus padbergi" Verhoeff, 1938 (Diplopoda: Spirobolida): histology and histochemistry. Arthropoda Sel 11: 135-142

Fontanetti CS, Nogarol LR, Souza RB, Perez DG, Maziviero GT (2011) Bioindicators and biomarkers in the assessment of soil toxicity. In: Pascucci S (ed) Soil Contamination, 1st edn. InTech, Rijeka, pp $143-168$

Fontanetti CS, Moreira-De-Sousa CM, Pinheiro TG, Souza RB, Francisco A (2015) Diplopoda-digestive system. In: Minelli A (ed) Treatise on zoology-anatomy, taxonomy, biology, 2nd edn. LeidenBoston, Brill, pp 109-128

Fytili D, Zabaniotou A (2008) Utilization of sewage sludge in EU application of old and new methods - a review. Renew Sust Energ Rev $12: 116-140$

Garcia CFH, Souza RB, de Souza CP, Christofoletti CA, Fontanetti CS (2017) Toxicity of two effluents from agricultural activity: comparing the genotoxicity of sugar cane and orange vinasse. Ecotox Environ Saf 142:216-221

Godoy JAP, Fontanetti CS (2010) Diplopods as bioindicators of soils: analysis of midgut of individuals maintained in substract containing sewage sludge. Water Air Soil Pollut 210:389-398

Gupta SC, Sharma A, Mishra M, Mishra RK, Chowdhuri DK (2010) Heat shock proteins in toxicology: how close and how far? Life Sci J 86(11-12):377-384

Haynes RJ, Murtaza G, Naidu R (2009) Inorganic and organic constituents and contaminants of biosolids. Adv Agron 104:165-267

Hightower LE (1991) Heat shock, stress proteins, chaperons, and proteotoxicity (meeting review). Cell 66:191-197

Hopkin SP, Read HJ (1992) The biology of millipedes. Oxf Univ, Press, Oxford

Kammenga JE, Dallinger R, Donker MH, Köhler HR, Simonsen V, Triebskorn R, Weeks JM (2000) Biomarkers in terrestrial invertebrates for ecotoxicological soil risk assessment. Rev Environ Contam Toxicol 164:93-147

Kiang JG, Tsokos GC (1998) Heat shock protein 70 kDa: molecular biology, biochemistry, and physiology. Pharmacol Ther 80:183-201

Kiikkila O, Pennanen T, Perkiomaki J, Derome J, Fritze H (2002) Organic material as a copper immobilising agent: a microcosm study on remediation. Basic Appl Ecol 3:245-253

Köhler HR (2002) Localization of metals in cells of saprophagous soil arthropods (Isopoda, Diplopoda, Collembola) Microsc Res Techniq 56:393-401

Köhler HR, Triebskorn R, Stöcker W, Kloetzel PM, Alberti G (1992) The $70 \mathrm{kD}$ heat shock protein (hsp70) in soil invertebrates: a possible tool for monitoring environmental toxicants. Arch Environ Con Tox 22(3):334-338

Köhler HR, Körtje KH, Alberti G (1995) Content absorption quantities and intracellular storage sites of heavy metals in Diplopoda (Arthropoda). Biometals 8:37-46

Köhler HR, Rahman B, Gräff S, Berkus M, Triebskorn R (1996) Expression of the stress-70 protein family (hsp70) due to heavy metal contamination in the slug, Deroceras reticulatum: an approach to monitor sublethal stress conditions. Chemosphere 33(7):13271340

Kumar S, Gopal K (2001) Impact of distellery effluent on physiological consequences in the freshwater teleost Channa punctatus. Bull Environ Contam Toxicol 66:617-622

Lara AI, Andreoli CV, Pegorini ES (2007) Environmental impact assessment and monitoring of final sludge disposal. In: Andreoli CV, Von Sperling M, Fernandes F (eds) Sludge Treatment and Disposal. Iwa Publishing, London, pp 226-236

Liu T, Pan L, Cai Y, Miao J (2015) Molecular cloning and sequence analysis of heat shock proteins 70 (HSP70) and 90 (HSP90) and 
their expression analysis when exposed to benzo(a)pyrene in the clam Ruditapes philippinarum. Gene 555(2):108-118

Lüchmann KH, Clark MS, Bainy AC, Gilbert JA, Craft JA, Chipman JK, Thorne MAS, Mattos JJ, Siebert MN, Schroeder DC (2015) Key metabolic pathways involved in xenobiotic biotransformation and stress responses revealed by transcriptomics of the mangrove oyster Crassostrea brasiliana. Aquat Toxicol 166:10-20

Mahmood K, Jadoon S, Mahmood Q, Irshad M, Hussain J (2014) Synergistic effects of toxic elements on heat shock proteins. Biomed Res Int 2014:1-17

Malaspina O, Silva-Zacarin ECM (2006) Cell markers for ecotoxicological studies in target organs of bees. Braz J Morphol Sci 23(3/4): 303-309

Marinho JFU, Correia JE, Marcato ACC, Pedro-Escher J, Fontanetti CS (2014) Sugar cane vinasse in water bodies: impact assessed by liver histopathology in tilapia. Ecotox Environ Saf 110:239-245

Mayer MP, Bukau B (2005) Hsp70 chaperones: cellular functions and molecular mechanism. Cell Mol Life Sci 62(6):670-684

Merlini VV, Nogarol LR, Marin-Morales MA, Fontanetti CS (2012) Toxicity of trifluralin herbicide in a representative of the edaphic fauna: histopathology of the midgut of Rhinocricus padbergi (Diplopoda). Microsc Res Tech 75:1361-1369

Mondal S, Singhb RD, Patra AK, Dwivedi BS (2015) Changes in soil quality in response to short-term application of municipal sewage sludge in a typic haplustept under cowpea-wheat cropping system. Environ Nanotechnol Monit Manag 4:37-41

Mukhopadhyay I, Nazir A, Saxena DK, Chowdhuri DK (2003) Heat shock response: hsp 70 in environmental monitoring. J Biochem Mol Toxicol 17(5):249-254

Nadeau D, Plante I, Morrow G, Tanguay RM (2001) Evaluation for Hsp70 as a biomarker of effect of pollutants on the earthworm Lumbricus terrestres. Cell Stress Chaperon 6:153-163

Nascimento CWA, Barros DAS, Melo EEC, Oliveira AB (2004) Alterações químicas em solos e crescimento de milho e feijoeiro após aplicação de lodo de esgoto. R Bras Ci Solo 28:385-392 (in Portuguese)

Nascimento IA, Pereira SA, Leite MBNL (2008) Biomarcadores como instrumentos preventivos de poluição. In: Zagatto PA, Betoletti E (eds) Ecotoxicologia: Princípios e Aplicações. RiMa, São Carlos, pp 413-432 (in Portuguese)

Natal-da-luz T, Tidona S, Van Gestel CAM, Morais PV, Sousa JP (2009) The use of collembola avoidance tests to characterize sewage sludges as soil amendments. Chemosphere 77(11):1526-1533

Natal-da-Luz T, Ojeda G, Costa M, Pratas J, Lanno RP, Van Gestel CAM, Sousa JP (2011) Shortterm changes of metal availability in soil. II: the influence of earthworm activity. Appl Soil Ecol 49:178-186

Nogarol LR, Fontanetti CS (2010) Acute and subchronic exposure of diplopods to substrate containing sewage mud: Tissular responses of the midgut. Micron 41:239-246

Pedro-Escher J, Maziviero GT, Fontanetti CS (2014) Mutagenic action of sugarcane vinasse in the Tradescantia pallida test system. J Ecosys Ecograph 4:145. doi:10.4172/2157-7625.10001

Pedro-Escher J, Christofoletti CA, Ansoar-Rodríguez Y, Fontanetti CS (2016) Sugarcane vinasse, a residue of ethanol industry: toxic, cytotoxic and genotoxic potential using the Allium cepa test. J Environ Prot 7:602-612
Perez DG, Fontanetti CS (2011) Assessment of the toxic potential of sewage sludge in the midgut of the diplopod Rhinocricus padbergi. Water Air Soil Poll (Print) 128:437-444

Polla BS, Kantengwa S, Francois D, Salvioli S, Franceschi C, Marsac C, Cossarizza A (1996) Mitochondria are selective targets for the protective effects of heat shock against oxidative injury. Proc Natl Acad Sci U S A 93:6458-6463

Rahul JS, Naz F, Siddique YH (2015) Evaluation of the toxic potential of cefatoxamine in the third instar larvae of transgenic Drosophila melanogaster. Chem Biolo Interact 233:71-80

Raij BV, Cantarella HM (1997) In: Raij B, Van Cantarella H, Quaggio JA, AMC F (eds) Recomendações de adubação e calagem para o Estado de São Paulo, 2nd edn. Rev Atual. Instituto Agronômico, Campinas, pp 56-59 (in Portugese)

Ryan JA, Hightower LE (1996) Stress proteins as molecular biomarkers for environmental toxicology. Stress-Inducible Cell Responses 77: 411-424

Santamaría J, Toranzos GA (2003) Enteric pathogens and soil: a short review. Int Microbiol 6:5-9

Sharma SK, Goloubinoff P, Christen P (2008) Heavy metal ions are potent inhibitors of protein folding. Biochem Biophys Res Commun 372(2):341-345

Silva-Zacarin ECM, Chauzat MP, Zeggane S, Drajnudel P, Schurr F, Faucon JP, Malaspina O, Engler JA (2012) Protocol for optimization of histological, histochemical and immunohistochemical analyses of larval tissues: application in histopathology of honey bee. Curr Microsc Contrib Adv Sci Technol 1:696-703

Silveira MLA, Alleoni LRF, Guilherme LRG (2003) Biosolids and heavy metals in soils. Sci Agric 60(4):793-806

Sosinka A, Rost-Roszkowska MM, Vilimova J, Tajovský K, KszukJendrysik M, Chajec L, Sonakowska L, Kaminska K, Hyra M, Poprawa I (2014) The ultrastructure of the midgut epithelium in millipedes (Myriapoda, Diplopoda). Arthropod Struct Dev 43: 477-492

Souza TS, Fontanetti CS (2011) Morphological biomarkers in the Rhinocricus padbergi midgut exposed to contaminated soil. Ecotoxicol Environ Saf 74:10-18

Souza TS, Christofoletti CA, Bozzatto V, Fontanetti CS (2014) The use of diplopods in soil ecotoxicology - a review. Ecotoxicol Environ Saf 103:68-73

Sreedhar AS, Csermely P (2004) Heat shock proteins in the regulation of apoptosis: new strategies in tumour therapy. Pharmacol Ther 101: 227-257

Tamás MJ, Sharma SK, Ibstedt S, Jacobson T, Christen P (2014) Heavy metals and metalloids as a cause for protein misfolding and aggregation. Biomol Ther 4(1):252-267

Urani C, Melchioretto P, Morazzoni F, Canevali C, Camatini M (2001) Copper and zinc uptake and HSP70 expression in HepG2 cells. Toxicol in Vitro 15(4-5):497-502

Valko MMHCM, Morris H, Cronin MTD (2005) Metals, toxicity and oxidative stress. Curr Med Chem 12(10):1161-1208

Wang L, Yang C, Song L (2013) The molluscan HSP70s and their expression in hemocytes. I S J 10:77-83

Zanger M, Alberti G, Kuhn M, Kölher HR (1996) The stress-70 protein family in diplopods: induction and characterization. J Comp Physiol B 165:622-627 